\title{
Interspecific Transformation in Azotobacter
}

\author{
By MIRA SEN AND S. P. SEN \\ Microbiology Laboratory, Department of Botany, \\ Kalyani University, Nadia, West Bengal, India
}

(Received 5 February 1965)

\begin{abstract}
SUMMARY
This paper describes the results obtained in experiments on interspecific transformation in Azotobacter. When Azotobacter chroococcum was transformed with the DNA of $A$. vinelandii 6-10\% of the colonies differed from the parent strain in colour, colony character and biochemical characteristics. Some of the transformant strains had higher nitrogen-fixing capacities than had the receptor strain. Transformants obtained by treatment of $\boldsymbol{A}$. vinelandii with the DNA of $\boldsymbol{A}$. chroococcum also had different colour, colony characteristics and capacity to grow in nutrient broth and peptone, but their nitrogen-fixing capacity was decreased.
\end{abstract}

\section{INTRODUCTION}

Genetic transformation in micro-organisms has numerous possibilities apart from its utility in genetic analysis. The characters transferred hitherto by this process include resistance to antibiotics and certain enzymes concerned with the production of capsule, specific polysaccharides, antigens and several cellular metabolites. Ravin (1961) listed some 20 bacterial species which have been found to be transformable. We record here observations concerning interspecific transformation between two species of the free-living nitrogen-fixers Azotobacter chroococcum and A. vinelandii.

\section{METHODS}

The strain of Azotobacter vinelandii used in this work was originally obtained through the courtesy of Professor R. H. Burris (University of Wisconsin). In most of the work described here a dark brown non-segregating strain AzCF of $A$. chroococcum was used. This was isolated from local soil samples by the enrichment plate method. The cultures were usually grown on Ashby's nitrogen-free mannitol medium having the following composition: mannitol, $10.0 \mathrm{~g}$; $\mathrm{K}_{2} \mathrm{HPO}_{4}, 0.5 \mathrm{~g}$.; $\mathrm{MgSO}_{4} .7 \mathrm{H}_{2} \mathrm{O}, 0 \cdot 2 \mathrm{~g}$.; $\mathrm{NaCl}, 0 \cdot 2 \mathrm{~g}$. $\mathrm{MnSO}_{4}$, trace; $\mathrm{FeCl}_{3}$, trace; distilled water, $1000 \mathrm{ml}$.

DNA extraction. In preliminary experiments several methods of DNA extraction were tried. The methods of McCarty \& Avery (1946), Anagnostopoulos \& Spizizen (1961), Marmur (1961) and Colter, Brown \& Ellem (1962) all yielded good results. Lysozyme, sodium deoxycholate and sodium lauryl sulphate were useful for the disruption of the bacteria. The method finally adopted was as follows: the bacteria were ground with alumina in $50 \mathrm{ml}$. of saline + EDTA (containing $0 \cdot 15 \mathrm{M}-\mathrm{NaCl}$ and $0.1 \mathrm{M}-\mathrm{EDTA}, \mathrm{pH} 8.0) ; 1.5 \mathrm{~g}$. sodium citrate and $2.5 \mathrm{ml}$. of a $1 \%(\mathrm{w} / \mathrm{v})$ solution of

Vol. 40, No. 3 was issued 17 November 1965 
sodium deoxycholate were added. After $15 \mathrm{~min} .2 \mathrm{ml}$. of $25 \%(\mathrm{w} / \mathrm{v})$ lauryl sulphate were added and the mixture warmed on a water bath at $60^{\circ}$ for $10 \mathrm{~min}$. This was followed by addition of solid $\mathrm{NaCl}$ to a final concentration $\mathrm{M}$. An equal volume of water-saturated phenol was added followed by centrifugation at $4^{\circ}$ for $30 \mathrm{~min}$. The upper aqueous layer was removed and re-extracted with water-saturated phenol for $10 \mathrm{~min}$. in the cold, the mixture being stirred with a magnetic stirrer. The liquid was again centrifuged, the upper layer extracted with ether 4 or 5 times for 10-20 min., traces of ether removed from it and left at $0^{\circ}$ for several hours, centrifuged and the supernatant fluid added to an equal volume of $95 \%(v / v)$ ethanol in water. The DNA which was collected on a glass rod was dissolved in $9 \mathrm{ml}$. dilute saline citrate $(0.15 \mathrm{M}-\mathrm{NaCl}+0.015 \mathrm{M}$-sodium citrate) and shaken with an equal volume of chloroform + isoamyl alcohol (24+1 by vol.) for $15 \mathrm{~min}$. and centrifuged. This operation was repeated twice and the DNA precipitated by addition of $95 \%(v / v)$ ethanol in water. After centrifugation the DNA was dispersed in half the volume of supernatant $0 \cdot 15 \mathrm{M}-\mathrm{NaCl}+0.015 \mathrm{M}$-sodium citrate. RNA was removed by incubation with ribonuclease $\left(50 \mu \mathrm{g} . / \mathrm{ml}\right.$.) at $37^{\circ}$ for $30 \mathrm{~min}$., followed by centrifugation and further washing with chloroform + isoamyl alcohol. The DNA was re-precipitated with ethanol, dissolved in dilute saline citrate buffer and 0.54 volume isopropyl alcohol added dropwise with stirring. The DNA threads were collected on a glass rod, and placed in $70 \%(\mathrm{v} / \mathrm{v})$ ethanol in water and then absolute ethanol was added slowly to a concentration of $95 \%(\mathrm{v} / \mathrm{v})$ ethanol. After centrifugation the DNA was finally dissolved in $\mathbf{0 . 8 5} \% \mathrm{NaCl}$ solution (normal saline).

Genetic markers. The characters of the Azotobacters which were used as genetic markers were the brown melanin pigment, colony characteristics, fermentation reactions and nitrogen-fixing capacity. Ashby's nitrogen-free mannitol agar media in Petri dishes were seeded with a suspension of the donor strain, incubated, and the bacteria harvested $72 \mathrm{hr}$ later by gently scraping-off the gummy growth from the surface of the agar. The organisms were then suspended in normal saline and their DNA isolated by the procedure described above.

Transformation. For transformation a loopful of a $22 \mathrm{hr}$ growth of a receptor strain was suspended in $2 \mathrm{ml}$. normal saline to provide a concentration of $10^{7}$ organisms $/ \mathrm{ml}$. and incubated with DNA of the donor strain at $37^{\circ}$ for $30 \mathrm{~min}$. to $1 \mathrm{hr}$. At the end of this incubation period dilutions of the bacterial suspension were plated on Ashby's mannitol agar and incubated at room temperature (28-30 ${ }^{\circ}$ ) for 7-14 days. Prolonged incubation was useful for the development of the melanin pigment. Colonies bearing resemblance to any character of the donor strain which was absent from the recipient strain were transferred to agar slopes for further study.

Pigment formation. The melanin-type pigment was extracted according to the procedure of Dawes (1941) with slight modifications: a bacterial suspension was boiled for $10 \mathrm{~min}$. and the insoluble residue digested for $48 \mathrm{hr}$ with $100 \mathrm{ml}$. of $1 \%$ pepsin in $\mathrm{KCl}+\mathrm{HCl}$ buffer ( $\mathrm{pH} \mathrm{2.0}$ ); a little toluene was added and the mixture shaken. The sediment was washed with distilled water, centrifuged and hydrolysed with $4 \%(\mathrm{w} / \mathrm{v}) \mathrm{NaOH}$, the boiling being continued for $15 \mathrm{~min}$. The brown pigment was estimated with a Unicam absorptiometer at $400 \mathrm{~m} \mu\left(E_{\mathbf{4 0 0}}\right)$. For qualitative comparisons of amounts of pigment, suspensions of young cultures of similar bacterial concentrations were used directly for spectrophotometry. 
Nitrogen-fixing capacity was estimated by a micro-Kjeldahl determination of the total- $\mathbf{N}$ of the crop of organisms obtained on Ashby's nitrogen-free mannitol medium.

\section{RESULTS}

Transformation of Azotobacter chroococcum with

\section{A. vinelandii DNA}

When Azotobacter chroococcum was transformed with the DNA of $A$. vinelandii $6-10 \%$ of the colonies obtained through dilution plating were found to be different from the parent colonies. Colonies of the original parent strain of $A$. chroococcum were dark coloured, smooth and glistening but never raised. Colonies of the donor strain of $A$. vinelandii were colourless and raised. The 'transformants' showed much lighter shades of brown, some being completely colourless and others raised and very

Table 1. Characters of transformants obtained by treatment of Azotobacter chroococcum with $A$. vinelandii $D N A$

\begin{tabular}{|c|c|c|c|c|}
\hline \multirow[b]{2}{*}{ Organisms } & \multirow[b]{2}{*}{$\begin{array}{l}\text { Colony } \\
\text { characters }\end{array}$} & \multicolumn{2}{|c|}{ Growth in } & \multirow[b]{2}{*}{$\begin{array}{l}\text { Utilizatio } \\
\text { of sucrose }\end{array}$} \\
\hline & & $\begin{array}{l}\text { Nutrient } \\
\text { broth }\end{array}$ & $\begin{array}{c}\text { Peptone } \\
\text { water }\end{array}$ & \\
\hline \multicolumn{5}{|l|}{ Parent strains } \\
\hline A. chroococcum (strain AZCF) & Deep brown, gummy & - & ++ & ++ \\
\hline A. vinelandii (strain Azv) & $\begin{array}{l}\text { Colourless, very gummy, } \\
\text { raised }\end{array}$ & ++ & \pm & +++ \\
\hline \multicolumn{5}{|l|}{ Transformant isolates } \\
\hline Az CV 1 & White, gummy & - & + & ++ \\
\hline $\mathrm{Az}$ CV 2 & White, gummy & - & ++ & ++ \\
\hline Az CV 3 & White, gummy & $+t$ & + & + \\
\hline $\mathrm{Az} \mathrm{CV} 4$ & Faint brown & - & - & +++ \\
\hline $\operatorname{Az} \operatorname{Cv} 5$ & White, gummy & ++ & ++ & +++ \\
\hline Az CV 6 & White, gummy & ++ & - & ++ \\
\hline
\end{tabular}

gummy. In several colonies which produced pigment the rate of pigment production was much slower than by the parent strain. Colonies which were faintly brown or white and gummy were used for detailed investigation. The biochemical characteristics of six selected isolates together with a brief description of the features are given in Table 1. All the transformants fermented mannitol, sucrose and xylose like the parent strain, but they differed to some extent in their capacity to grow on peptone or nutrient broth. The AzCF strain of $A$. chroococcum used in this work was unable to grow in nutrient broth, whereas the isolate of $A$. vinelandii grew well in this medium. The transformants $\mathrm{Cv} 3$ and $\mathrm{cv} 5$ utilized peptone and nutrient broth whereas the isolate cv 4 did not grow in either of these media. The isolate cv 6 grew well on nutrient broth but not in peptone water.

The pigment content and nitrogen-fixing capacities of these isolates are shown in Table 2. It will be seen that all the transformants shown in this table had very little of the melanin pigment, whereas the receptor strain of Azotobacter chroococcum AZCF was quite rich in the pigment. The actual pigment content of the parent strain was much higher than the value shown in the table because the method of extraction used could solubilize only a part of the total pigment, and the pigment which 
was tightly bound could not be separated by any method. The pigments of the transformants however were almost completely extracted. The strain of $A$. vinelandii used had a higher capacity for fixing nitrogen than the receptor AzCF strain of $A$. chroococcum. The improvement observed in nitrogen-fixing capacity was quite remarkable and all the transformants studied fixed at least twice as much nitrogen as the receptor AZCF strain of $A$. chroococcum.

\section{Table 2. Pigment content and nitrogen-fixing capacity of transformant Azotobacter isolates}

Pigment present in $1 \mathrm{mg}$. dry wt. organism dissolved in $1 \mathrm{ml} .4 \%(\mathrm{w} / \mathrm{v}) \mathrm{NaOH}$.

\begin{tabular}{|c|c|c|}
\hline Organism & $\underset{E_{400}}{\text { Pigment }}$ & $\begin{array}{l}\text { Total } \\
\mathbf{N}(\%)\end{array}$ \\
\hline A. chroococcum & $0 \cdot 10$ & 1.5 \\
\hline $\begin{array}{l}\text { A. vinelandii } \\
\text { A. chroococcum transformed with } A \text {. } \\
\text { vinelandii DNA }\end{array}$ & 0.015 & $3 \cdot 6$ \\
\hline $\mathrm{AZ} \mathrm{CV} 1$ & 0.02 & 3.0 \\
\hline $\mathrm{Az} \mathrm{CV} 2$ & 0.01 & $3 \cdot 1$ \\
\hline $\mathrm{AZ} \mathrm{CV} 3$ & 0.02 & - \\
\hline $\mathrm{Az} \mathrm{CV} 4$ & 0.02 & 3.0 \\
\hline $\mathrm{AZ} \mathrm{CV} 5$ & 0.02 & $3 \cdot 6$ \\
\hline $\mathrm{Az}$ Cv 6 & 0.02 & $3 \cdot 4$ \\
\hline
\end{tabular}

Table 3. Characters of transformants obtained by treatment of Azotobacter vinelandii with $A$. chroococcum $D N A$

\begin{tabular}{|c|c|c|c|c|}
\hline \multirow[b]{2}{*}{ Organism } & \multirow[b]{2}{*}{$\begin{array}{c}\text { Colony } \\
\text { characters }\end{array}$} & \multicolumn{2}{|c|}{ Growth in } & \multirow[b]{2}{*}{$\begin{array}{l}\text { Utilization } \\
\text { of sucrose }\end{array}$} \\
\hline & & $\begin{array}{c}\text { Nutrient } \\
\text { broth }\end{array}$ & $\begin{array}{c}\text { Peptone } \\
\text { water }\end{array}$ & \\
\hline \multicolumn{5}{|l|}{ Parent strains } \\
\hline A. chroococcum (strain AZCF) & Deep brown, gummy & - & ++ & ++ \\
\hline A. vinelandii (strain Azv) & $\begin{array}{l}\text { White, very gummy, } \\
\text { raised }\end{array}$ & ++ & \pm & $+t+$ \\
\hline \multicolumn{5}{|l|}{ Transformant isolates } \\
\hline AZ VCI & Deep brown & - & + & $+t+$ \\
\hline Az vc2 2 & Deep brown & - & \pm & ++ \\
\hline Az $\mathbf{v C 3}$ & Deep brown & - & - & ++ \\
\hline $\operatorname{Az} \operatorname{ve} 4$ & $\begin{array}{l}\text { White, raised, slightly } \\
\text { wrinkled }\end{array}$ & - & - & +++ \\
\hline
\end{tabular}

\section{Transformation of Azotobacter vinelandii with A. chroococcum DNA}

Attempts to transform Azotobacter vinelandii to $A$. chroococcum have also been successful. Several transformant strains have been isolated which have the property of melanin production as indicated by the formation of brown pigment. The biochemical characteristics, pigment production, and nitrogen-fixing capacities are given in Tables 3 and 4 . While the strain of $A$. vinelandii used grows well on nutrient broth but poorly, if at all, in peptone and the converse is true for $A$. chroococcum, the transformants varied considerably in their capacity to utilize these substrates. All of them, however, could metabolize sucrose, mannitol and xylose, 
though in varying degrees. The three transformants vc1, vc 2 and $\mathrm{vc} 3$ increased considerably in pigment production. The nitrogen-fixing capacity was, however, lowered in all the cases and intermediate values were obtained.

\section{Table 4. Pigment content and nitrogen-fixing capacity of transformant Azotobacter isolates}

Relative amounts of pigment present in $1 \mathrm{mg}$. dry wt. organism dissolved in $1 \mathrm{ml} .4 \%$ $(\mathrm{w} / \mathrm{v}) \mathrm{NaOH}$.

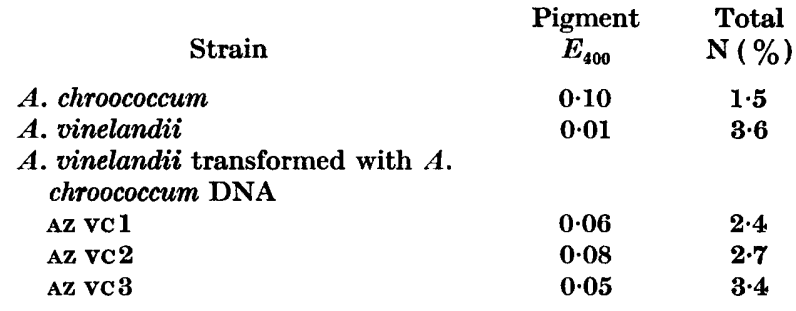

DISCUSSION

The investigations described here indicate the transformability of Azotobacter chroococcum and $A$. vinelandii. The property of the production of brown melanin pigment, alteration in the consistency of the gum produced and the shape of the colony can be acquired by the receptor strain when treated with the DNA of the donor strain. The strains of both the species of Azotobacter studied were fairly sensitive to penicillin and streptomycin, and the property of resistance to these antibiotics could not be studied.

Genetic implication of the findings will be presented in a subsequent paper. It is, however, of considerable interest that when Azotobacter chroococcum is treated with the DNA of the non-pigment-producing $A$. vinelandii a large number of transformants failed to produce the melanin pigment. Whether this is due to the acquisition of the capacity to elaborate a substance which interferes with the production of melanin, or there was some position effect, cannot be decided at present. The capacity to fix nitrogen can apparently be modified and this observation also merits careful consideration and further biochemical studies.

The significance of interspecific transformation in Azotobacter in speciation cannot be assessed at present. Variations in the shape of the colony, pigment content and gum production of the transformants are, however, indicative of such a possibility since strains of Azotobacter isolated from a given soil are very often found to vary considerably in their morphological features and biochemical characteristics, as has been found in the case of the transformants described here. The significance of genetic transformation in speciation and variability of soil micro-organisms has been discussed elsewhere (Biswas, Sen \& Sen, 1964).

\section{REFERENCES}

Anagnostopoulos, C. \& Spizizen, J. (1961). Requirements of transformation in Bacillus subtilis. J. Bact. 81, 741.

Biswas, G. D., Sen, M. \& Sen, S. P. (1964). Genetic transformation in soil microorganisms and its probable significance in the variability and speciation of microorganisms. Symposium on 'Frontiers of Plant Sciences'. Bull. Bot. Soc. Bengal, 18 (Suppl.), p. 29 (abstract). 
Colter, J. S., Brown, R. A. \& Ellem, K. A. O. (1962). Observations on the phenol method of isolation of deoxyribonucleic acid. Biochim. biophys. Acta, 55, 31.

Dawes, B. (1941). The melanin content of the skin of Rana temporaria under normal conditions and after prolonged light and dark adaptation. A photometric study. $J$. exp. Biol. 18, 26.

McCarty, M. \& Avery, O. T. (1946). Chemical nature of the substance inducing transformation of pneumococcal types. III. Improved method for the isolation of the transforming substance and its application to Pneumonococcus type II, III and VI. $J$. exp. Med. 83, 97.

Marmur, J. A. (1961). Procedure for the isolation of deoxyribonucleic acid from microorganisms. J. mol. Biol. 3, 208.

Ravin, A. W. (1961). The geneties of transformation. Advanc. Genet. 10, 61. 